\title{
Kontribusi Kemampuan Motorik Terhadap Kemampuan Teknik Dasar Pada Atlet Ssb (Sekolah Sepakbola) Balai Baru Kota Padang
}

\author{
Ilfan Yozi naldi ${ }^{1}$, Roma Irawan ${ }^{1}$ \\ ${ }^{1}$ Fakultas Ilmu Keolahragaan, Universitas Negeri Padang, Indonesia \\ Universitas Negeri Jakarta, Indonesia.
}

\section{Informasi Artikel}

Diterima 21-05-2020

Direvisi 28-05-2020

Dipublikasikan 03-06-2020

\section{Keyword:}

Motor Ability

Basic Football Techniques

\begin{abstract}
The problem in this study is the low performance of the Balai Baru Soccer School in Padang. The purpose of this study was to determine the relationship between motor skills with the basic technical abilities of soccer players in the Kota Baru Padang Soccer School. This type of research is correlational. This research was conducted in January 2020 at the Balai Baru Football Field in Kota Padang. The population in this study were all new hall soccer school players, totaling 130 players. The sampling technique used purposive sampling, so the number of samples in this study were 25 players. The instruments in this study were 1) motor ability test, which consisted of a) suttle run test, b) ball throwing test, c) balance test, d) running speed test; 2) football basic technical ability test consisting of a) passing control test, b) dribbling test, c) shooting test. Data analysis techniques using the product moment correlation formula. The results of this study are that there is a contribution between motor skills to the basic technical abilities of the Balai Baru Football School players in Kota Padang with the acquisition of a count of 0.467> a table of 0.396, and a determination of 21.83\%. This means that motor skills contribute to the basic technical abilities of the Padang Baru City Soccer School players
\end{abstract}

(C) 2020 The Authors. Published by Universitas Negeri Padang. This is an open access article under the CC BY-NC-SA license https://creativecommons.org/licenses/by-nc-sa/4.0

\section{Penulis Korespondensi:}

Ilfan Yozi Naldi

Universitas Negeri padang

Email: ilfanyozinaldi96@gmail.com

\section{PENDAHULUAN}

Dewasa ini di Indonesia, sepakbola merupakan salah satu olahraga yang perlu ditingkatkan prestasinya, tidak hanya orang dewasa, tetapi anak-anak pun sudah banyak memainkannya dan menjadikan sepakbola olahraga paling popular di dunia.Hal ini erat kaitannya dengan berdirinya asosiasi tertinggi sepak bola dunia (FIFA), sepakbola juga termasuk olahraga yang terjangkau dari segi biaya serta tempat bermain, karena tempat bermain sepakbola dimainkan dalam lapangan terbuka yang berbentuk persegi panjang, di atas rumput. Tujuan dilakukannya pembinaan olahraga prestasi secara ilmiah sudah seharusnya menjadi landasan dalam proses pembibitan dan pembinaan atlet dari suatu program untuk mencapai prestasi yang tinggi, baik yang bersifat nasional dan daerah, serta menyelenggarakan kompetisi secara berjenjang dan berkelanjutan (yandri, badri, Tohidin,2019).

Menurut Darussalam (2018) Sepakbola merupakan sebuah permainan yang beregu, yang masing-masing regu terdiri penjaga gawang, pemain belakang, pemain tengah dan pemain depan. Sepakbola juga sudah menjadi sebuah olahraga yang dipertandingkan di setiap daerah di seluruh 
Indonesia.Pertandingan sepakbola juga tidak kalah gengsinya dengan olahraga populer lainnya, bahkan sepakbola juga menjadi olahraga favorit dari setiap daerah-daerah tertentu di Indonesia.Permainan sepakbola merupakan permainan yang sangat menarik, karena dapat dimainkan oleh putra putri di semua golongan umur, disamping itu pemain juga dituntut memiliki keterampilan bermain, keterampilan fisik, kekuatan, dan daya tahan tubuh yang tinggi. Sejarah sepak bola di Indonesia diawali dengan berdirinya Persatuan Sepakbola Seluruh Inonesia (PSSI) di Yogyakarta pada 19 April 1930 dengan pimpinan Soeratin sosrosoegondo.

Dalam perkembangannya PSSI telah memperluas kompetisi sepakbola dalam negeri, di antaranya dengan penyelenggaraan Liga Super Indonesia, Divisi Utama, Divisi Satu, dan Divisi Dua untuk pemain non amatir, serta Divisi Tiga untuk pemain amatir. Selain itu, PSSI juga aktif mengembangkan kompetisi sepakbola wanita dan kompetisi dalam kelompok umur tertentu (U15, U-17, U-19, dan U-23)

Dalam proses belajar sepakbola, terdapat faktor-faktor yang akan menentukan hasil belajar tersebut. Faktor-faktor tersebut adalah faktor bawaan atau faktor internal yang dimiliki oleh individu itu sendiri, seperti bakat, minat, motivasi, dan intelegensi.Selain faktor tersebut, adalah faktor eksternal atau faktor yang berasal dari luar individu, seperti pelatih, guru, waktu latihan, penggunaan sarana dan prasarana latihan.

Keterampilan bermain sangat diperlukan oleh setiap tim yang melakukan pertandingan sepakbola, tanpa teknik dasar yang bagus maka pemain tersebut tidak dapat bermain sepakbola dengan baik dan benar, begitupun dengan tim yang tidak memiliki pemain dengan teknik dasar yang bagus, maka tim tersebut akan sulit dalam memenang sebuah pertandingan jika menghadapi lawan yang memiliki teknik yang baik, maka dari itu hendaknya setiap individu yang dalam kelompok atau club sepakbola harus melatih teknik dasar mereka. Pelatih memiliki peran penting dalam proses pembentukan keterampilan bermain sepakbola ini.

Menurut Ramadhan (2017) Teknik-teknik dasar dalam sepak bola seperti passing (mengumpan), shooting (menendang), driblling (menggiring), throwing (melempar bola), dan heading (menyudul bola).Menurut Febrianto (2017) Teknik dasar merupakan komponen yang paling penting dalam permainan sepak bola.Perlu diketahui untuk dapat bermain sepakbola perlu mempunyai keterampilan dasar dalam bermain sepakbola.

Untuk meningkatan kualitas teknik dalam suatu cabang olahraga akan lebih maksimal jika didukung oleh faktor intelegensi agar sesuai dengan penggunaan metode latihan yang diinginkan.Di dalam permainan sepakbola, sebuah teknik yang baik dapat dihasilkan dengan kualitas gerakan yang maksimal, contohnya seseorang yang hendak melakukan passing, pemain harus mampu mengukur lambat kuatnya passing yang dilakukan kepada teman supaya bola tidak mudah diambil lawan, untuk mencapai kemampuan tersebut diperlukan kemampuan intelegensi yang baik pula, ada banyak faktor yang mendukung kemampuan tersebut dan di antaranya adalah kemampuan kemampuan motorik yang baik. Pada dasarnya semua cabang olahraga membutuhkan kemampuan kemampuan motorik, karena kemampuan tersebut menunjukkan kualitas dariindividu dalam mempelajarigerakan.

SSB Balai Baru merupakan salah satu klub yang sudah cukup lama terbentuk di kota Padang, SSB ini berdiri tahun 1994, tempat Jl. Raya Balai Baru, Sungai Sapih. SSB Balai Baru ini pernah mengikuti beberapa kejuaranan sepakbola, yaitu 1) liga danone U-12 pada tahun 2017 s.d 2018 hanya sampai babak fase kualifikasi grup, 2) piala walikota kota padang U-12 pada tahun 2018 SSB Balai Baru mendapatkan peringkat 3, kemudian piala walikota kota U-12 pada tahun 2019 prestasi SSB balai baru hanya sampai babak 32 besar, berdasarkan kejuaraan yang pernah diikuti oleh SSB Balai Baru terlihat SSB Balai Baru tiga tahun belakangan belum mendapatkan pencapaian prestasi yang baik. Dari observasi yang dilakukan penulis melihat beberapa kekurangan dari atlet SSB Balai Baru adalah masih rendahnya keterampilan dalam bermain sepakbola.Terlihat dari kesalahan-kesalahan atlit dalam melakukan passing, sehingga rekan dalam permainan tidak dapat menerima passing yang diberikan dengan maksimal, kemudian pemain sering melakukan kesalahan pada setiap kali shooting, pemain sering melakukan kesalahan dalam melakukan shooting kegawang sehingga bola yang dilepaskan cendrung melenceng dari gawang. Selain itu ada hal lain yang menyebabkan rendahnya keterampilan bermain sepakbola SSB Balai Baru yaitu terlihat pelatih kurang memahami kemampuan motorik khusus atlit, sehingga latihan yang diberikan untuk meningkatkan passing skill atlit tidak efektif, tidak ada kriteria khusus 
dalam pengembangan keterampilan motorik atlit, terutama dalam pengelompokan kemampuan berdasarkan kemampuan motorik, sehingga latihan tidak efektif dalam mengembangkan teknik passing pada SSB Balai Baru Kota Padang. Namun dari keseluruhan atlet SSB Balai Baru, hanya beberapa atlet yang memiliki keterampilan bermain sepakbola yang baik.

Banyak faktor yang menjadi penyebab rendahnya keterampilan bermain sepakbola SSB Balai Balai Baru, seperti kondisi fisik dalam menjalani proses latihan. Atlet yang memiliki kondisi fisik bagus akan mampu menjalani latihan dengan intensitas berapapun, berbeda dengan keadaan atlet SSB Balai Baru, karena bentuk tubuh atlet yang terlalu kurus dan ada yang terlalu gemuk. Hal ini akibat pengaturan pola makan yang buruk.Metode latihan yang tidak tepat dan kurangnya variasi dari metode yang dilakukan juga menjadi faktor rendahnya keterampilan bermain sepakbola atlet. Hal ini dari kurangnya motivasi berlatih atlet karena metode latihannya selalu sama dan tidak disesuaikan.

Dari banyaknya faktor yang mempengaruhi diduga penyebab dari kekalahan SSB Balai Baru adalah banyaknya kegagalan dalam melakukan teknik dasar sepakbola, seperti passing, dribbling dan shooting didugasebagai penyebab dari kekalahan SSB Balai Baru, hal ini dikarenakan pelatih tidak memperhatikan kemampuan kemampuan motorik dalam mengembangkan keterampilan passing atlit.

\section{METODE}

Jenis penelitian yang akan digunakan yaitu, penelitian korelasi atau korelasional. Penelitian ini dilaksanakan pada tanggal 21 Januari s.d 22 Januari 2020 di lapangan sepakbola Balai Baru Padang yang bertempat di Kota Padang Provinsi Sumatra Barat. Populasi penelitian ini adalah seluruhatlet putra klub Sepakbola Balai Baru Padang.Berdasarkan informasi dari pelatih, jumlah atlet putra sebanyak 130 orang. Penarikan sampel dilakukan dengan teknik purposive sampling, menurut Margono (2003) purposive sampling adalah" pemilihan sekelompok subjek yang didasarkan atas ciri-ciri tertentu yang diterapkan berdasarkan tujuan penelitian". Berdasarkan teknik penarikan sampel di atas peneliti memilah berdasarkan kelas umur (13 tahun).Dengan demikian dapat diperoleh jumlah sampel pada kelompok umur 13 sebanyak 25 orang. Intrumen dalam penelitian ini adalah 1) tes kemampuan motorik yang terdiri dari: a) Tes Shuttle Run 4 x 10 meter, b) Tes Lempar Tangkap bola, c) Tes Stork Stand Positional Balance, d) Tes Lari Cepat 30 meter dan 2) tes keterampilan teknik dasar sepakbola yang terdiri dari: a) Tes sepak dan tahan bola (Passing dan Stopping,Winarno (2006), b) Tes Menggiring bola (dribbling), c) Tes menembak bola ke sasaran (shooting). Teknik analisis data menggunakan teknik analisis korelasi sederhana.

\section{HASIL DAN PEMBAHASAN}

\section{Hasil Penelitian}

\section{a) Kemampuan Motorik (X)}

Pengukuran kemampuan motorik dilakukan dengan tes kemampuan motorikterhadap 25 orang sampel, diperoleh skor tertinggi 59.81 dan skor terendah 29,06. rata-rata (mean) sebesar 50,02, Simpangan baku (standar deviasi) sebesar 6,47. Distribusi frekuensi kecepatan reaksi sebagaimana tampak pada tabel 1 di bawah ini.

Tabel 1. Distribusi Frekuensi Hasil DataKemampuan motorik Pemain sekolah sepakbola Balai Baru Kota Padang.

\begin{tabular}{cccc}
\hline No. & Kelas Interval & Frekuensi Absolut $(\mathrm{Fa})$ & Frekuensi Relatif $(\%)$ \\
1. & $>59.72$ & 1 & 4 \\
2. & $53.25-59.71$ & 6 & 24 \\
3. & $46.78-53.24$ & 12 & 48 \\
4. & $40.31-46.77$ & 5 & 20 \\
5. & $<40.30$ & 1 & 4 \\
& Total & 25 & 100 \\
\hline
\end{tabular}

Dari 25 sampel, 1 orang (4\%) memiliki kemampuan motorik pada kelas interval $>59.72$ berada pada kategori baik sekali, 6 orang (24\%) memiliki hasil kemampuan motorik berada pada 
kelas interval 53.25 - 59.71 berada pada kategori baik, 12 orang (48\%) memiliki hasil kemampuan motorik pada kelas interval 46.78 -53.24, berada pada kategori sedang, 5 orang (20\%) memiliki hasil kemampuan motorik pada kelas interval 40.31 -46.77, berada pada kategori kurang dan 1 orang (4\%) memiliki kemampuan motorik pada kelas interval $<40,30$, berada pada kategori kurang sekali. Dari analisis data diperoleh kemampuan kemampuan motorik pemain sekolah sepakbola balai baru memiliki rata-rata 50,02, maka kemampuan kemampuan motorik pemain Sekolah Sepakbola Balai Baru Kota Padang berada pada kategori sedang.

\section{b) Kemampuan Teknik Dasar Sepakbola (Y)}

Pengukuran kemampuan teknik dasar sepakbola dilakukan dengan tes kemampuan teknik dasar sepakbolaterhadap 25 orang sampel, diperoleh skor tertinggi 54,50 dan skor terendah 29,25. rata-rata (mean) sebesar 43,21, Simpangan baku (standar deviasi) sebesar 8,11. Distribusi frekuensi kemampuan teknik dasar sepakbola sebagaimana tampak pada tabel 2 di bawah ini.

Tabel 2. Distribusi Frekuensi Hasil DataKemampuan teknik dasar sepakbola Pemain sekolah sepakbola Balai Baru Kota Padang

\begin{tabular}{cccc}
\hline No. & Kelas Interval & Frekuensi Absolut (Fa) & Frekuensi Relatif (\%) \\
1. & $>61$ & 0 & 0 \\
2. & $53-60$ & 2 & 8 \\
3. & $46-52$ & 11 & 44 \\
4. & $37-45$ & 4 & 16 \\
5. & $\leq 36$ & 8 & 32 \\
& Total & 25 & 100 \\
\hline
\end{tabular}

\section{Pembahasan}

Dari 25 sampel, tidak ada pemain yang memiliki kemampuan teknik dasar sepakbola pada kelas interval $>61$ berada pada kategori baik, 2 orang (8\%) memiliki hasil kemampuan teknik dasar sepakbola berada pada kelas interval 53-60 berada pada cukup, 11 orang (44\%) memiliki hasil kemampuan teknik dasar sepakbola pada kelas interval 46-52, berada pada kategori sedang, 4 orang (16\%) memiliki hasil kemampuan teknik dasar sepakbola pada kelas interval 37 - 45, berada pada kategori kurang dan 8 orang (32\%) memiliki kemampuan teknik dasar sepakbola pada kelas interval <36, berada pada kategori kurang sekali. Dari analisis data diperoleh kemampuan kemampuan teknik dasar sepakbola pemain Sekolah Sepakbola Balai Baru memiliki rata-rata 43,21, maka kemampuan kemampuan teknik dasar sepakbola pemain Sekolah Sepakbola Balai Baru Kota Padang berada pada kategori kurang.

\section{KESIMPULAN}

\section{Terdapat Kontribusi Antara Kemampuan Motorik Terhadap Kemampuan Teknik Dasar Pemain Sekolah Sepakbola Balai Baru Kota Padang}

Menurut Hakim (2013), Motorik kasar adalah gerakan tubuh yang menggunakan sebagian besar otot otot besar atau seluruh anggota tubuh yang di pengaruhi kamatangan anak itu sendiri meliputi gerak dasar lokomotor, non lokomotor,dan manipulative. Menurut kartika dan S.Latinulu (2002), kemampuan motorik kasar adalah kemampuan anak yang bekaitan dengan gerakan yang di pengaruhi oleh keterampilan otot otot besar.

Berdasarkan penjelasan diatas maka motorik merupakan hal yang sangat penting bagi setiap orang.Sehingga ini bisa menjadi hal yang penting juga bagi setiap atlet sepakbola.menurut Sepriadi (2017), Kemampuan motorik adalah merupakan kulitas kemampuan seseorang yang dapat mempermudah dalam melakukan kemampuan gerak.

Hasil analisis korelasi antara kemampuan motorik (X) dengan kemampuan teknik dasar sepakbola (Y) pemain Sekolah Sepakbola Balai Baru kota padang, maka diperoleh $r_{\text {hitung }} 0,467>$ 
$\mathrm{r}_{\text {tabel }}$ 0,396. Dengan besar desterminasi 21,83\%, Artinya terdapat kontribusi antara kemampuan motorik dengan kemampuan teknik dasar pemain Sekolah Sepakbola Balai Baru Kota Padang. Untuk menguji signifikan koefisien korelasi antara kemampuan motorik dengan teknik dasar sepakbola Pemain Sekolah Sepakbola Balai Baru Kota Padang.dilakukan uji t, ternyata $t_{\text {hitung }}=3,92$ $>t_{\text {tabel }}$ 1,71. Dengan demikian dapat disimpulkan bahwa terdapat hubungan yang berarti (signifikan) antara kemampuan motorik dengan kemampuan teknik dasar pemain Sekolah Sepakbola Balai Baru Padang diterima kebenarannya secara empiris.

Hasil penelitian ini menunjukkan bahwa semangkin baik kemampuan gerak motorik seorang atlet maka semangkin bagus teknik dasar yang dimiliki seorang atlet sepakbola.Sukintaka, (2001), Kemampuan motorik merupakan perkembangan unsur kematangan dan pengendalian gerak tubuh, keterampilan motorik dan kontrol motorik.Sedangkan menurut Kirkendall, (1980), kemampuan motorik adalah kualitas umum yang ditingkatkan melalui latihanlatihan.Kemampuan motorik merupakan faktor fisik yang dapat dikembangkan melalui belajar gerak.Berdasarkan teori yang dikemukakan di atas maka gerak motorik merupakan kemampuan pengendalian gerak tubuh, kemampuan gerak motorik dapat ditingkatkan melalui latihan latihan. Hasil penelitian ini diperkuat oleh hasil penelitian Sutanta (2010), menyatakan menurut penelitian ini tingkat kemampuan gerak anak mempunyai pengaruh dalam proses belajar gerak khususnya penguasaan keterampilan (skill) dasar permainan sepak bola. Hal ini juga disebutkan dalam hasil penelitian Nusufi (2016), terdapat hubungan positif dan signifikan terhadap kemampuan motor ability dengan keterampilan bermain Sepakbola pada klub Himadirga FKIP Unsyiah. Kemampuan motor ability (X) memberikan kontribusi terhadap keterampilan bermain sepakbola (Y) sebesar 82,81\%, artinya nilai kontribusi motor ability sangat tinggi yang menunjukkan sumbangan yang sangat bagus terhadap keterampilan sepakbola dan 17,19\% artinya di pengaruhi oleh faktor lain yaitu emosional, motivasi dan percaya diri.

Berdasarkan penjabaran penelitian di atas dapat menjadi acuan bagi setiap pelatih, bahwa untuk melatih teknik dasar seorang atlet sepakbola maka harus pula melatih motoriknya. Menurut Hakim (2017), menyatakan Terdapat interaksi antara model pembelajaran dengan kamampuan motorik terhadap hasil belajar keterampilan dasar sepakbola. Menurut Wicaksono (2013) kemampuan motorik adalah proses dimana seorang individu mengembangkan kemampuan geraknya menjadi respon yang terkoordinasi, terkontrol, dan teratur. Hal ini menuntut pelatih untuk mampun membuat program latihan yang sesuai dengan kebutuhan pada atlet.Untuk mendapatkan hasil latihan teknik dasar yang bagus, maka pelatih juga harus memperhatikan gerak motorik pada atlet. Dengan kemampuan motorik yang bagus akan memudahkan pelatih untuk melatih teknik dasar. Menurut Dermawan (2016), Terdapat interaksi antara pemberian umpan balik dan kemampuan motorik terhadap hasil belajar shooting siswa SMP. Untuk siswa yang memiliki kemampuan motorik tinggi lebih efektif dalam meningkatkan hasil belajar shooting jika diberikan umpan balik langsung, sedangkan untuk siswa yang memiliki kemampuan motorik rendah ternyata pemberian umpan balik tertunda lebih efektif dalam meingkatkan hasil belajar shooting.

\section{KESIMPULAN}

Berdasarkan analisis data dan pembahasan yang telah dipaparkan terdahulu, maka dapat disimpulkan terdapat kontribusi antara kemampuan motorik terhadap kemampuan teknik dasar pemain Sekolah Sepakbola Balai Baru Kota Padang. Artinya kemampuan motorik memberikan kontribusi terhadap kemampuan teknik dasar pemain Sekolah Sepakbola Balai Baru Kota Padang. 


\section{DAFTAR PUSTAKA}

Al Anshar, Darussalam. "Pengaruh Metode Drill Terhadap Kemampuan Teknik Dasar Passing Sepakbola Siswa Sekolah Sepakbola (Ssb) Sheva Sukakersa." (2018): 154-157.

Cahyo Wicaksono, D. I. D. I. K. "Survey Kemampuan Motorik Siswa Sekolah Dasar Muhammadiyah Kelas Iv Se-Kecamatan Taman Sidoarjo Tahun Ajaran 2012-2013." Jurnal Pendidikan Olahraga dan Kesehatan 1.1 (2013).

Darmawan, Aries Dian. "HUBUNGAN ANTARA PERSEPTUAL MOTORIK DENGAN KETERAMPILAN SEPAKBOLA SSB PUTRA BANGSA KLATEN." Pendidikan Jasmani Kesehatan dan Rekreasi 3.3 (2016).

Febrianto, Ferry. "Analisis Teknik Dasar Permainan Sepakbola Klub Sinar Harapan Tulangan Sidoarjo pada Liga 3 Regional Jatim."Jurnal Prestasi Olahraga 2.1 (2017).

Hakim, Luqman. "PENGARUH PEMBELAJARAN TGFU DAN KOOPERATIF TERHADAP HASIL BELAJAR KETERAMPILAN DASAR SEPAKBOLA DENGAN KEMAMPUAN MOTORIK TINGGI DAN KEMAMPUAN MOTORIK." Didaktik: Jurnal Ilmiah PGSD STKIP Subang 3.1 (2017): 146161.

Hakim, Arif Rohman."Pengaruh usia dan latihan keseimbangan terhadap kemampuan motorik kasar anak tunagrahita kelas bawah mampu didik sekolah luar biasa."Journal of physical education and sports 2.1 (2013).

Kartika, Vita, and S. Latinulu."Faktor-faktor yang mempengaruhi kemampuan motorik anak usia 12-18 bulan di keluarga miskin dan tidak miskin."Penelitian Gizi dan Makanan (The Journal of Nutrition and Food Research)25.2 (2002).

Kirkendall, Don R. 1980. Pengukuran dan Evaluasi Untuk Guru Pendidikan Jasmani.IKIP. Jakarta.

Nusufi, Maimun. "Hubungan Kemampuan Motor Ability dengan Keterampilan Bermain Sepak Bola pada Klub Himadirga Unsyiah."JURNAL PEDAGOGIK OLAHRAGA 2.1 (2016): 1-10.

Ramadan, Gilang. "Pengaruh metode pembelajaran dan motivasi belajar terhadap hasil belajar passing sepakbola."JUARA: Jurnal Olahraga 2.1 (2017): 1-10.

Sepriadi, Sepriadi. "Kontribusi status gizi dan kemampuan motorik terhadap kesegaran jasmani siswa sekolah dasar."Jurnal Keolahragaan 5.2 (2017): 194-206.

Sukintaka.(2001). Teori Pendidikan Jasmani. Solo: Esa Grafika.

Sutanta, Nur. "Perbedaan pengaruh pendekatan pembelajaran dan kemampuan gerak terhadap keterampilan dasar sepak bola." Universitas Sebelas Maret: Surakarta(2010).

Winarno. 2006. Tes Keterampilan Olahraga. Malang: Laboratorium Fakultas Ilmu Keolahragaan Universitas Negeri Malang.

Yandri, Badri, Hanif, and Didin Tohidin. "TINJAUAN KETERAMPILAN TEKNIK DASAR SEPAKBOLA PEMAIN SENTRAL SEPAKBOLA SEKOLAH DASAR KOTA SOLOK." JURNAL STAMINA 2.1

(2019): 451-459. 